\title{
Dynamic Simulation of Heat Transfer through External Building Constructions
}

\author{
Pitel J. ${ }^{1}$, Khovanskyi S. ${ }^{2}$, Pavlenko I. ${ }^{2}$, Mizakova J. ${ }^{*}$ \\ ${ }^{1}$ Faculty of Manufacturing Technologies with a seat in Presov, Technical University of Kosice, \\ 1 Bayerova St., 08001 Presov, Slovakia; \\ ${ }^{2}$ Faculty of Technical Systems and Energy Efficient Technologies, Sumy State University, \\ 2 Rymskogo-Korsakova St., 40007 Sumy, Ukraine
}

\section{Article info:}

Paper received:

The final version of the paper received:

Paper accepted online:
January 20, 2019

April 24, 2019

April 29, 2019
*Corresponding Author's Address:

jana.mizakova@tuke.sk

\begin{abstract}
In the paper, some approaches to dynamic modeling of heat transfer through external building constructions are presented. The model of heat transfer dynamics through a wall was designed on the base of mathematical describing of an energy balance for the elementary layer of a plane wall. The wall was considered as a continuum with continuously distributed thermal resistance and capacity. Based on the designed analytical mathematical model, a simulation model in MATLAB/Simulink environment was developed. These dynamic models of heat transfer through the wall with real materials parameters and also through the window with real thermal parameters were simulated and some simulation results are presented in the paper.
\end{abstract}

Keywords: dynamic modeling, mathematical model, heat transfer.

\section{Introduction}

Heating, cooling, and lighting are the primary energy consumers in buildings, but heating is predominant [1]. To improve energy efficiency and reduce energy consumption, it is highly important to obtain patterns of energy use, climatic conditions, heat transfer characteristics, and ventilation requirements.

Heating models can be installed on the basis of system identification and statistical methods to assess the energy consumption of buildings by combining existing data. Since the interior of the building is not always meet the requirements of comfort, the reaction of the building should be corrected through the heating or airconditioning systems that act as controlled heat or cold sources [2].

Due to a high number of insulating materials are widely used in new construction and modern building envelope has more complicated internal and external structures [3], the problem of dynamic simulation of heat transfer through external building constructions is the urgent scientific problem.

Previously developed simplified models are able to describe existing building systems with the aim of prediction for air-conditioning system optimal control [4]. However, these models need to be supplemented by detailed physical models of heat transfer.

\section{Literature Review}

A number of research works are aimed at ensuring the precise dynamic simulation of heat transfer through external building constructions. Particularly, the paper [5] presents the analysis of energy demand in residential buildings for different climates by means of dynamic simulation.

The paper [6] presents a solution of the problem of heat transfer through walls for energy independent building applications in the form of an optimized, thermally controlled storage using phase change materials integrated to building walls.

Thermal dynamic modeling and simulation of a heating system for a multi-zone office building equipped with demand controlled ventilation using MATLAB/Simulink is presented in the paper [7].

Using the CFD methods for numerical simulation of the heat and mass transfer processes is proposed in the articles [8, 9].

Modeling of conduction transfer functions for typical thermal bridges identified in BIM data is proposed in the paper [10].

Comparison of steady-state and dynamic building energy simulation programs is discovered in the research work [11]. 


\section{Research Methodology}

\subsection{Mathematical description of heat transfer dynamics through a wall}

For the design of the mathematical model of heat transfer dynamics through the wall, we have considered a single-layered plane wall, where the wall has been considered as a continuum with continuously distributed thermal resistance and capacity. We have chosen elementary layer with following parameters, $m$ (Figure 1):

$d y$ - thickness of an elementary layer in a plane wall; $d_{i}-$ thickness of the whole single-layered plane wall; $y-$ a distance of elementary layer from the heated surface.

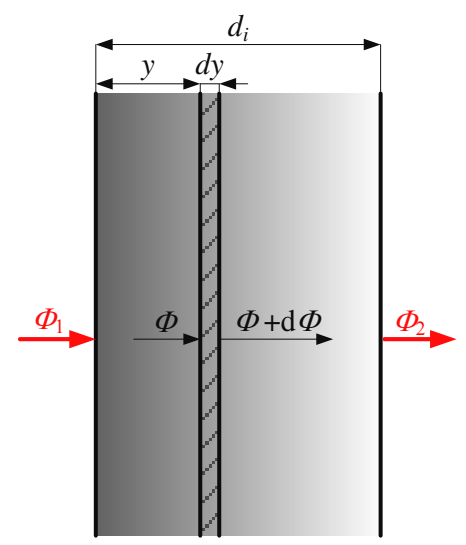

Figure 1 - Single-layered plane wal

Let's others variable has been used for mathematical description: $\Phi_{1}$ - heat flow supplied into the heated wall surface, $\mathrm{W} ; \Phi_{2}-$ heat flow taken away from the cooled wall surface, W; $\Phi$ - heat flow inputs into unit surface of layer $d y$, and heat flow $(\Phi+d \Phi)$ outputs from it, $\mathrm{W}$.

Material parameters of a single-layered plane wall which have been used for mathematical description: $c$ - specific heat capacity, $\mathrm{J} /(\mathrm{kg} \cdot \mathrm{K}) ; \rho$ - volume weight, $\mathrm{kg} / \mathrm{m}^{3} ; \lambda$ - heat conductivity of wall material, $\mathrm{W} /(\mathrm{m} \cdot \mathrm{K})$.

If a wall of the real building is considered, which consists of several layers (Figure 2) with various parameters of each material, the materials parameters and the temperatures on both sides of such wall can be denote as follows: $\theta_{w 1}$ - temperature of the heated wall surface, $\mathrm{K}$; $\theta_{w 2}$ - temperature of the cooled wall surface, $\mathrm{K} ; \theta_{w}-$ temperature of elementary layer, $\mathrm{K} ; d_{i}$-i-layer thickness, $\mathrm{m} ; \lambda_{i}-$ heat conductivity of i-layer material, $\mathrm{W} /(\mathrm{m} \cdot \mathrm{K})$.

The parameters of the multi-layered wall are calculated as follows: $R_{i}=d_{i} / \lambda_{i}$ - thermal resistance of i-layer with thickness $d_{i}, \mathrm{~K} \cdot \mathrm{m}^{2} / \mathrm{W} ; d_{w}=\sum_{i=1}^{n} d_{i}-$ thickness of multi-layered wall, which consists from layers with thickness $d_{i}, \mathrm{~m} ; R=\sum_{i=1}^{n} R_{i}$ - thermal resistance of multilayered wall, which consists from layers with thermal resistance $R_{i}, \mathrm{~K} \cdot \mathrm{m}^{2} / \mathrm{W} ; U=1 / R$ - heat transfer coefficient, $\mathrm{W} /\left(\mathrm{m}^{2} \cdot \mathrm{K}\right)$.

According to [12] the heat energy does not originate either does not dissolve in considering an elementary layer of the wall. Then the difference of input heat and output heat in the layer has to be equal to the time variation of the energy in a layer.

Let's $c$ is a specific heat capacity and $\rho$ is a volume weight of the wall material, then:

$$
\Phi-(\Phi+\mathrm{d} \Phi)=\frac{\partial}{\partial t}\left(c \cdot \rho \cdot \theta_{w} \cdot \mathrm{d} y\right),
$$

where heat flow $d \Phi$ is:

$$
\mathrm{d} \Phi=\frac{\partial \Phi}{\partial y} \mathrm{~d} y .
$$

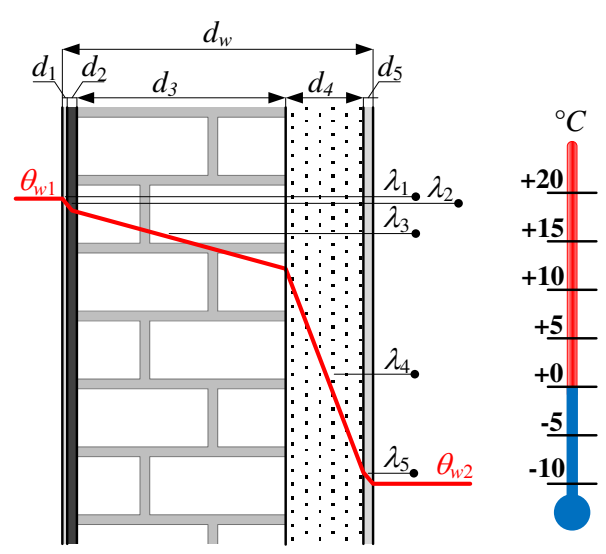

Figure 2 - Multi-layered plane wall

If specific heat capacity $c$ and volume weight $\rho$ of the used wall material are constant, then:

$$
-\frac{\partial \Phi}{\partial y}=c \cdot \rho \cdot \frac{\partial \theta_{w}}{\partial t} .
$$

According to Fourier's law, the heat flow is directly proportional to the temperature gradient

$$
\Phi=-\lambda \frac{\partial \theta_{w}}{\partial y},
$$

where $\lambda$ is the heat conductivity coefficient of the used wall material.

These partial differential equations (3) and (4) with relevant initial and border conditions completely describe non-stationary one-dimensional heat flow. After expression of dependent variables by their values and increments and their conversion to non-dimensional form $[13,14]$ we have got partial differential equations system of heat transfer dynamics through a wall:

$$
\begin{gathered}
\frac{\partial x_{\Phi}}{\partial y}+c \cdot \rho \cdot \frac{d_{w}}{\lambda} \frac{\partial x_{\theta v}}{\partial t}=0 \\
x_{\Phi}+d_{w} \frac{\partial x_{\theta w}}{\partial y}=0 .
\end{gathered}
$$


This system describes the dependence of nondimensional variables $x_{\Phi}$ for heat flows $\Phi$ and $x_{\theta w}$ for temperatures $\theta_{w}$, but it still needs to be supplemented by equations of heat transfer on both sides of the wall surfaces. In dimensionless form for the indoor surface area it is valid:

$$
x_{\Phi 1}=x_{\Phi 1}^{*}-\kappa_{1} \cdot x_{\theta w 1}=\left(x_{\theta a 2}-x_{\theta w 1}\right) \cdot h_{1}-\kappa_{1} \cdot x_{\theta w 1},
$$

where $x_{\Phi 1}^{*}$ includes also external effects on the heat flow transfer into the wall, $x_{\theta a 2}$ is the temperature of air warming the wall, $\kappa_{1}=h_{1} \cdot d_{w} / \lambda$, and $h_{1}$ is heat transfer coefficient between air and wall surface, $\mathrm{W} /\left(\mathrm{m}^{2} \cdot \mathrm{K}\right)$.

Similarly, for the outdoor surface area it is valid:

$$
x_{\Phi 2}=x_{\Phi 2}^{*}+\kappa_{2} \cdot x_{\theta v 2}=\left(x_{\theta v 2}-x_{\theta o}\right) \cdot h_{2}+\kappa_{2} \cdot x_{\theta v 2},
$$

where $x_{\Phi 2}^{*}$ includes external conditions of the heat flow transfer from the wall, $x_{\theta o}$ is the temperature of air cooling the wall, $\kappa_{2}=h_{2} \cdot d_{w} / \lambda$, and $h_{2}$ is heat transfer coefficient between the wall surface and air $\mathrm{W} /\left(\mathrm{m}^{2} \cdot \mathrm{K}\right)$.

Using Laplace transform and some substitutions (detailed described in [15]) we have got equations:

$$
\begin{aligned}
& \bar{X}_{\Phi 2}(p)=G_{1}(p) \cdot \bar{X}_{\Phi 1}(p)-G_{2}(p) \cdot \bar{X}_{\theta w 2}(p) ; \\
& \bar{X}_{\theta v 1}(p)=G_{3}(p) \cdot \bar{X}_{\Phi 1}(p)+G_{1}(p) \cdot \bar{X}_{\theta v 2}(p),
\end{aligned}
$$

where:

$$
\begin{gathered}
G_{1}(p)=\frac{1}{c h \sqrt{p}} ; \\
G_{2}(p)=\sqrt{p} \cdot \operatorname{th} \sqrt{p} ; \\
G_{3}(p)=\frac{\operatorname{th} \sqrt{p}}{\sqrt{p}} .
\end{gathered}
$$

Then using substitution solved in [15] and substitution $p=T_{s} \cdot s$, we have got transfer functions:

$$
\begin{gathered}
G_{1}(p)=\frac{24}{24+12 p+p^{2}}=\frac{24}{24+12 T_{s} s+\left(T_{s} s\right)^{2}} ; \\
G_{2}(p)=\frac{4\left(6 p+p^{2}\right)}{24+12 p+p^{2}}=\frac{4\left[6 T_{s} s+\left(T_{s} s\right)^{2}\right]}{24+12 T_{s} s+\left(T_{s} s\right)^{2}} ; \\
G_{3}(p)=\frac{120+20 p+p^{2}}{5\left(24+12 p+p^{2}\right)}=\frac{120+20 T_{s} s+\left(T_{s} s\right)^{2}}{5\left[24+12 T_{s} s+\left(T_{s} s\right)^{2}\right]},
\end{gathered}
$$

where $T_{s}=d^{2}{ }_{s} \cdot \rho \cdot c / \lambda$ is constant, which is depended on wall properties $d_{w}$ and

$$
\lambda=d_{w} \cdot R=d_{w} \cdot \sum_{i=1}^{n} R_{i}=d_{w} \cdot \sum_{i=1}^{n} \frac{d_{i}}{\lambda_{i}} .
$$

Based on equations (7)-(10) block diagram of heat transfer dynamics through a wall was designed and it is shown in Figure 3.

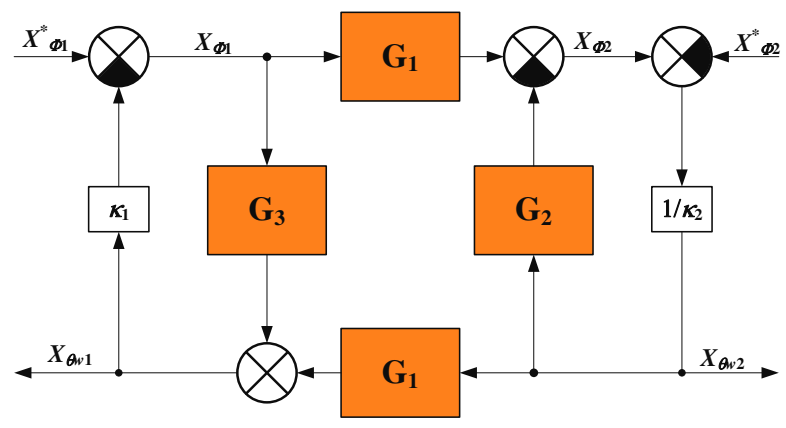

Figure 3 - Block diagram of heat transfer dynamics through a wall

\subsection{Simulation model of heat transfer dynamics}

In Figure 4, there is presented dynamic simulation model of heat transfer through a wall developed in MATLAB/Simulink environment. This model was designed on the base of the block diagram of heat transfer dynamics through a wall (Figure 3 ) corresponding to transfer functions (14)-(16) of partial differential equation system (9), (10).

According to (9) and (10), temperature $\theta_{w 1}$ of the heated wall surface and heat flow $\Phi_{2}$ taken away from cooled wall surface is calculated from heat flow $\Phi_{1}$ supplied into the heated wall surface and from temperature $\theta_{w 2}$ of the cooled wall surface. Heat flow $\Phi_{1}$ supplied into the heated wall surface is calculated using equation (7) with two inputs: temperature $\theta_{a 2}$ of air warming the wall and temperature $\theta_{w 1}$ of the heated wall surface. The temperature of the cooled wall surface $\theta_{w 2}$ is calculated using equation (8) and it serves as input into main parts of the model.

The main part of the model is Transfer Fcnblocks $G_{1 a}=G_{1 b}=G_{1}, G_{2}$, and $G_{3}$, which determine the dynamics of the system. Another important part of the model is hierarchical blocks named "standardize", which serve for calculation of main variables in the model.

\section{Results}

Using the model in Figure 4 we have simulated heat transfer through the real wall and through the real window, to compare different materials of multi-layered wall, thermal parameters, energy losses, etc.

Firstly, heat transfer through the real wall was simulated (Figure 5) with following real parameters, which have corresponded to parameters measured on typical building wall with thickness $d_{w}=0.520 \mathrm{~m}$, where the wall has consisted of an internal plaster with thickness $0.015 \mathrm{~m}$, external plaster with thickness $0.015 \mathrm{~m}$, internal isolation layer $0.150 \mathrm{~m}$, external isolation layer $0.050 \mathrm{~m}$, and finally brick layer thickness layer $0.290 \mathrm{~m}$. The wall material volume weight was $\rho=1400 \mathrm{~kg} / \mathrm{m}^{3}$, and its specific heat capacity $c=840 \mathrm{~J} /(\mathrm{kg} \cdot \mathrm{K})$. Thermal conductivity $\lambda$, $\mathrm{W} /(\mathrm{m} \cdot \mathrm{K})$, has been calculated as 


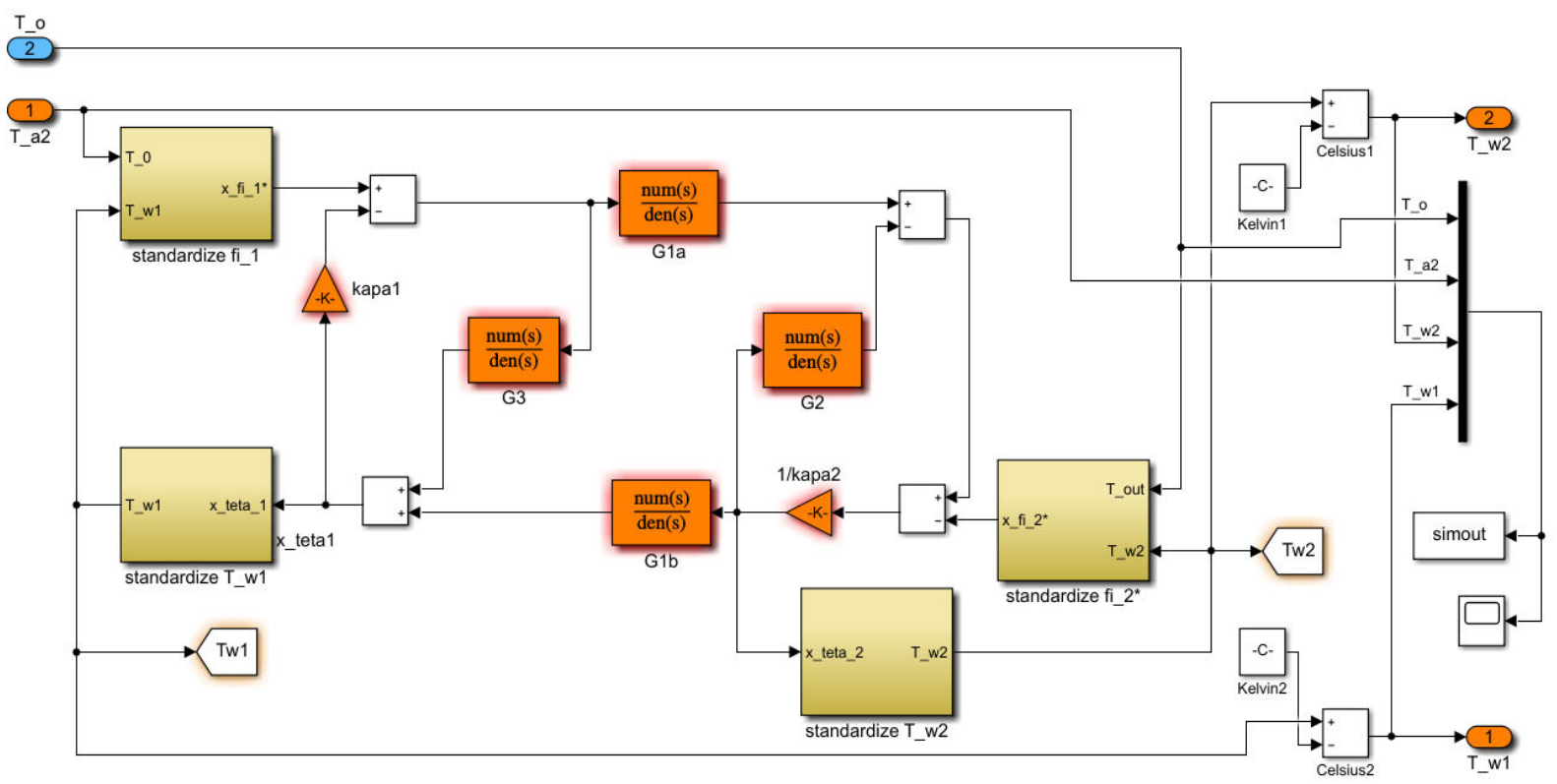

Figure4 - Dynamic simulation model of heat transfer through a wall

$$
\lambda=\frac{d_{w}}{R}
$$

where $R$ is thermal resistance obtained by formula (for the case of the total number of layers $n=5$ ):

$$
R=\sum_{i=1}^{5} \frac{d_{i}}{\lambda_{i}}
$$

Thermal conductivities of the individual wall layers, $\mathrm{W} /(\mathrm{m} \cdot \mathrm{K}): \lambda_{1}=0.70, \lambda_{2}=0.03, \lambda_{3}=0.52, \lambda_{4}=0.04$, and $\lambda_{5}=0.87$.
So, thermal conductivity of the simulated multilayered wall is $\lambda=0.15 \mathrm{~W} /(\mathrm{m} \cdot \mathrm{K})$.

Outdoor temperature $\theta_{o}$ has been simulated as a sine wave with period 86400 s (i. e. 24 hours), and amplitude $5{ }^{\circ} \mathrm{C}$. The temperature of heating water $\theta_{b 1}$ has been $50{ }^{\circ} \mathrm{C}$.

Next, heat transfer through the real wall was simulated (Figure 6) with the following real parameters: thermal resistance $R=1 \mathrm{~K} \cdot \mathrm{m}^{2} / \mathrm{W}, d_{w}=0.030 \mathrm{~m}$. Outdoor temperature $\theta_{o}$ has been simulated again as a sine wave with period $86400 \mathrm{~s}$ (i. e. 24 hours) and amplitude $5{ }^{\circ} \mathrm{C}$. The temperature of heating water $\theta_{b 1}$ has been $50{ }^{\circ} \mathrm{C}$.

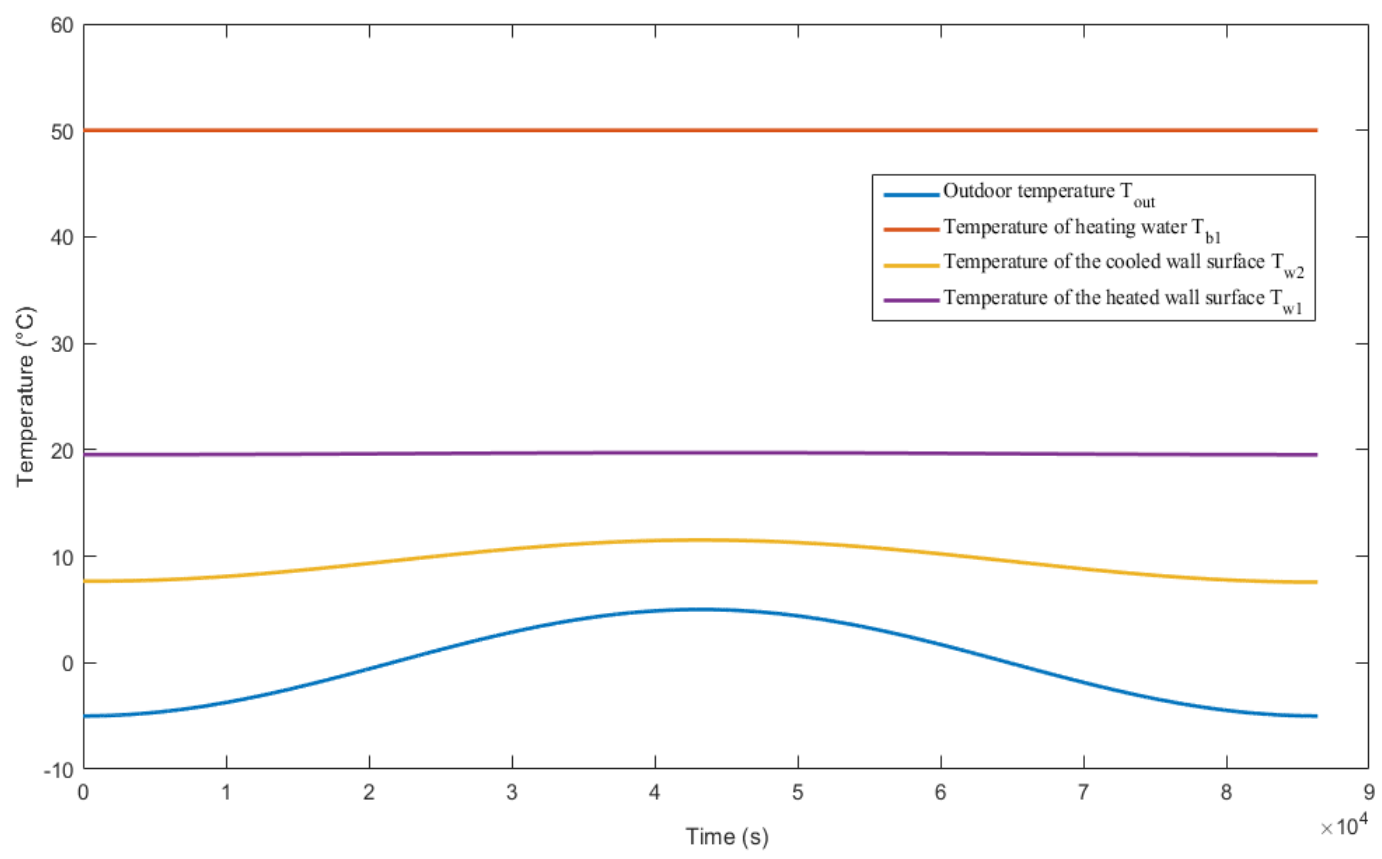

Figure 5 - Simulation results of heat transfer through the real wall: temperature of the heated wall surface $\theta_{w 1}\left(T_{w 1}\right)$, and temperature of the cooled wall surface $\theta_{w 2}\left(T_{w 2}\right)$ 


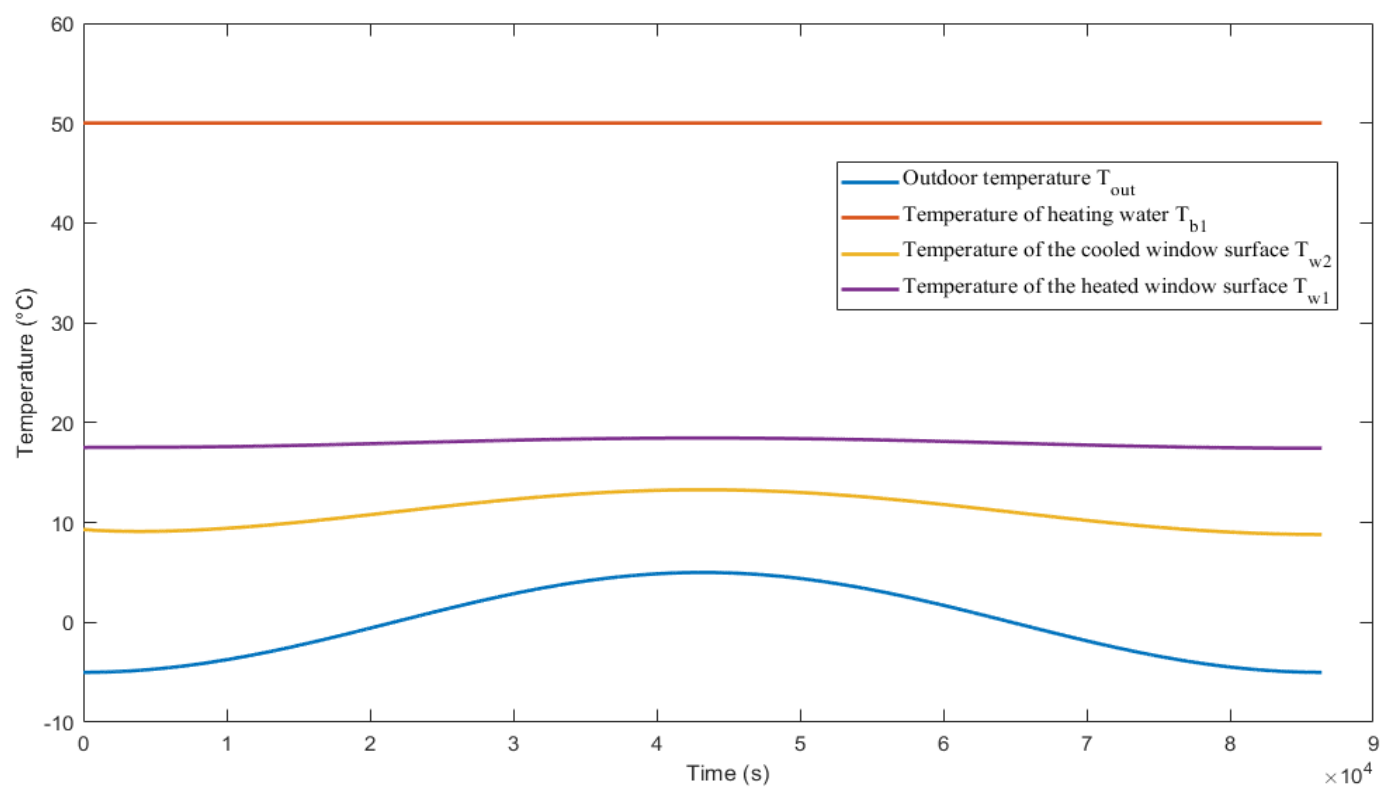

Figure 6 - Simulation results of heat transfer through the real window: temperature of the heated window surface $\theta_{w 1}\left(T_{w 1}\right)$, and temperature of the cooled window surface $\theta_{w 2}\left(T_{w 2}\right)$

\section{Conclusions}

To summarize, the described mathematical model of heat transfer dynamics through a plane wall has led to the system of partial differential equations which secondorder transfer functions were derived. Model parameters of single-layered and multi-layered plain walls were also described in the paper. Based on the designed analytical model of heat transfer through a wall, a dynamic simulation model in MATLAB/Simulink environment was developed. This model has been tested for different real wall material parameters, for example, a brick wall, insulated wall, etc. The tested model was also used for simulation of heat transfer through the real window.

Comparison of simulation results in Figures 5, 6 shows that the temperature of the heated wall surface is higher than the temperature of the heated window surface. Conversely, the temperature of the cooled wall surface is lower than the temperature of the cooled window surface. It shows that heat losses through the window with worse thermal properties are higher than through the wall with better thermal properties. So, the achieved simulation results have confirmed the right approach to model design.
From the point of view of model dynamics, it can be stated that the dynamic change in the outdoor temperature had an impact especially on the temperature of the cooled wall or window surface. This impact is with time delay given by system time constant. The achieved simulation results are in line with theoretical assumptions.

The designed and tested dynamic model of heat transfer through external building constructions is needed for simulation of the heating process control based on outdoor temperature compensation. So in the future work, this model will be implemented into a dynamic simulation model of the heating system containing model of heating body and a model of heating curves.

\section{Acknowledgments}

This work was supported by the Slovak Research and Development Agency under the contract No. APVV-150602.

The achieved results were partially supported by the Ministry of Education and Science of Ukraine under the research project No. 0117 U003931.

\section{References}

1. Perera, D. W. U., Pfeiffer, C. F., \& Skeie, N.-O. (2014). Modelling the heat dynamics of a residential building unit: Application to Norwegian buildings. Modeling, Identification and Control, Vol. 35(1), pp. 43-57, doi: 10.4173/mic.2014.1.4.

2. Missoum, A., Elmir, M., Bouanini, M., \& Draoui, B. (2016). Numerical simulation of heat transfer through the building facades of buildings located in the city of Bechar. International Journal of Multiphysics, Vol. 10(4), pp. 441-450.

3. Gao, Y., Roux, J. J., \& Zhao, L. H. (2007). A low-order thermal bridge dynamic model for building simulation. Proceedings: Building Simulation, pp. 281-286.

4. Xu, X., \& Wang, S. (2008). A simplified dynamic model for existing buildings using CTF and thermal network models. International Journal of Thermal Sciences, Vol. 47(9), pp. 1249-1262, doi: 10.1016/j.ijthermalsci.2007.10.011. 
5. Bianco, V., Rosa, M., Scarpa, F., \& Tagliafico, L. A. (2016). Analysis of energy demand in residential buildings for different climates by means of dynamic simulation. International Journal of Ambient Energy, Vol. 37(2), pp. 108-120, doi: $10.1080 / 01430750.2014 .907207$.

6. Wegmueller, R., Magnin, G., Robadey, J., \& Niederhauser, E.-L. (2018). Controlled active thermal storage in smart PCM walls for energy independent building applications. IEEE 5th International Conference on Renewable Energy: Generation and Applications, 17703462, doi: 10.1109/ICREGA.2018.8337575.

7. Behravan, A., Obermaisser, R., \& Nasari, A. (2017). Thermal dynamic modeling and simulation of a heating system for a multizone office building equipped with demand controlled ventilation using MATLAB/Simulink. IEEE International Conference on Circuits, System and Simulation, pp. 103-108, doi: 10.1109/CIRSYSSIM.2017.8023191.

8. Svoboda, Z., \& Kubr, M. (2011). Numerical simulation of heat transfer through hollow bricks in the vertical direction. Journal of Building Physics, Vol. 34(4), pp. 325-350, doi: 10.1177/1744259110388266.

9. Varukha, D. A., Smirnov V. A., Edl M., Demianenko M. M., Yukhymenko M. P., Pavlenko I. V., \& Liaposhchenko O. O. (2018). Simulation of separation and air classification processes of aerodisperse systems in the shelving device. Journal of Engineering Sciences, Vol. 5(1), pp. F5-F9, doi: 10.21272/jes.2018.5(1).f2.

10. Narowski, P., Stasierski, J., \& Wereszczynski, P. (2011). Modelling of conduction transfer functions for typical thermal bridges identified in BIM data. Proceedings of Building Simulation 2011: 12th Conference of International Building Performance Simulation Association, Vol. 12, pp. 1320-1327.

11. Veken, J., Saelens, D., Verbeek, G., \& Hens. H. (2004). Comparison of steady-state and dynamic building energy simulation programs. Buildings, Vol. IX, pp. 1-11

12. Cermak, J., Peterka, V., \& Zavorka, J. (1968). Dynamika Regulovaných Soustav v Tepelné Energetice a Chemii. Academia, Praha, Czech Republic [in Czech].

13. Pitel', J. (2007). Matematický model prestupu tepla stenou pre simuláciu riadenia procesu vykurovania. Acta Metallurgica Slovaca, Vol. 13(3), pp. 296-300 [in Slovak].

14. Mizakova, J., \& Pitel', J. (2017). An analytical dynamic model of heat transfer from the heating body to the heated room. MATEC Web of Conferences, Vol. 125, pp. 1-5.

15. Mizakova, J., Pitel', J., \& Hrehova, S. (2014). Some simulation results of heat transfer through the wall model. International Journal of Mathematical Models and Methods in Applied Sciences, Vol. 8(1), pp. 1-8.

\title{
Динамічне моделювання теплообміну через зовнішні будівельні конструкції
}

\author{
Пітель Я. ${ }^{1}$, Хованський C. ${ }^{2}$, Павленко I. ${ }^{2}$, Міжакова Я. ${ }^{1}$ \\ ${ }^{1}$ Факультет виробничих технологій у м. Прешов, Технічний університет м. Кошице, \\ вул. Баєрова, 1, 080 01, м. Прешов, Словаччина; \\ ${ }^{2}$ Факультет технічних систем та енергоефективних технологій, Сумський державний університет, \\ вул. Римського-Корсакова, 2, 40007, м. Суми, Україна
}

Анотація. У статті представлені теоретичний і числовий підходи до динамічного моделювання теплообміну через зовнішні будівельні конструкції. У результаті розроблено модель динаміки теплопередачі через стіну на основі математичного моделювання енергетичного балансу елементарного шару плоскої стінки. Стіна розглядалась як суцільне середовище з безперервно розподіленим тепловим опором і ємністю. На основі розробленого аналітичного підходу, що реалізує запропоновану математичну модель, розроблено імітаційну модель із застосуванням середовища MATLAB/Simulink. Продемонстровано динамічну модель теплопередачі через стіну з параметрами реальних матеріалів, а також через вікно $з$ реальними тепловими параметрами. Результати моделювання представлені графічно.

Ключові слова: динамічне моделювання, математична модель, теплообмін. 